ISSN 2078-6441. Вісник Львівського університету. Серія географічна. 2018. Випуск 52. С. 124-131.

Visnyk of the Lviv University. Series Geography. 2018. Issue 52. P. 124-131.

http:/ / dx.doi.org/10.30970/vgg.2018.52.10176

911.3:502.63:630(477.43)

\author{
едір іпт ч \\ ьвівський н ціон льний університет імені в н \\ вул. . орошенк , 41, 79007, м. ввів, кр їн, \\ e-mail: kfgeoresurs@ukr.net
}

бгрунтов но необхідність л ндш фтних к рт великого м сшт бу під ч с розроблення проектів і пропозицій щодо сільсько- і лісогоспод рського землекористув ння, т кож боротьби з ерозією грунтів.

пис но природні умови землекористув ння бинської сільської р ди т росинявського р-ну мельницької обл. т про н лізов но структуру земельних угідь. структурі земельних угідь перев ж ють екологічно дест білізув льні угіддя - рілля т землі, виведені із сільсько- т лісогоспод рського виробництв (господ рські будівлі т помешк ння, дороги, к р'єри, землі стороннього користув ння). они з йм ють 89,7 \% (зокрем , рілля - 87,3\%) від їхньої з г льної площі. н вп ки, екологічно ст білізув льні угіддя (с ди, п совищ, сінож ті, ч г рники, лісосмуги, ліси, болот, води) з йм ють незн чний відсоток від з г льної площі дослідної ділянки - 8,96. н слідок цього грунти, охоплені ерозією, ст новлять 87,3\% від їхньої з г льної площі. розія грунтів зумовил зниження їхньої родючості т зменшення врож йності сільськогоспод рських культур. ередньозв жені втр ти гумусу в грунт х орного горизонту (0-30 см) порівняно з повнопрофільними ет лон ми- н лог ми $(4,5 \%)$ ст новлять $1,1 \%$.

бгрунтов но перший крок створення ст лих л ндш фтно-екологічних систем 3 принципом відновлення земельних ресурсів і посилення процесів їхнього с морегулюв ння розширенням площі екологічно ст білізув льних земельних угідь з вдяки м лопродуктивним землям т їхньому розміщенню з ур хув нням скл дної морфологічної структури л ндш фтних систем. ндш фтні системи дослідної ділянки розподілено 3 генезою і типом їхього господ рського використ ння. рні землі повинні з йм ти не більше 45,4\% від 3 г льної площі території сільської р ди. окрем, 2,6\% рекомендов но використовув ти під польові зерно-п ропрос пні сівозміни і вирощув ння всіх сільськогоспод рських культур цієї зони 3 з стосув нням інтенсивних систем землеробств т широким впров дженням їхніх екологічних л нок; 27,8 \% - під польові зерно-п ропрос пні сівозміни і вирощув ння всіх сільськогоспод рських культур цієї зони з використ нням екологічних систем землеробств 3 умови оброблення грунту, сівби т догляду з посів ми в н прямі горизонт лей; $15,0 \%$ - під польові зерно-тр в'яні бо тр в'яно-зернові грунтоз хисні сівозміни з повним вилученням прос пних культур. е менше 51,2\% від з г льної площі дослідної ділянки повинні 3 йм ти б г торічні н с дження (с ди) $(1,6 \%)$, п совищ $(0,9)$, сінож ті $(20,9)$, лісосмуги $(0,05)$, ліси $(27,1)$, болот $(0,21)$, води $(0,54 \%)$. ешту $3,4 \%$ зй ють господ рські будівлі т помешк ння $(1,2 \%)$, дороги $(1,1)$, порушені землі (к р'єри) $(0,2)$, землі стороннього користув ння $(0,9 \%)$.

трим ні результ ти д ли змогу обгрунтув ти норми сприятливого співвідношення земельних угідь для території землекористув ння бинської сільської р ди, їхній н ліз свідчить, що для сильнорозчленов них височин лісостепу ст білізув льні угіддя м ють

(C) іпт ч ., 2018 
3 йм ти не менше 50-55\%. н вп ки, дест білізув льні - не більше 50-45 \% (зокрем , рілля 40-45\%).

лючові слов : оптиміз ція землекористув ння, ерозія грунтів, земельні угіддя, л ндш фтні системи.

и н решті м ємо усвідомити, що збереження якості не тільки земельних ресурсів, й природного довкілля, потрібно не лише людині як біологічному виду і соці льному орг нізму, й компонент м біоценозу (рослин м, тв рин м, гриб м і мікроорг нізм м).

е особливо кту льно з умов скл дної л ндш фтної будови лісостепу, для якого х р ктерн висок ч стк грунтів, охоплених площинною і лінійною ерозіями. метою 3 хисту грунтів від ерозії т поліпшення ст ну земель необхідно для кожного л ндш фту обгрунтув ти норми сприятливого співвідношення земельних угідь [1-3].

орми сприятливого співвідношення земельних угідь ми обгрунтув ли для території землекористув ння бинської сільської р ди т росинявського р-ну мельницької обл. н підст ві вл сних м тері лів грунтозн вчих обстежень 1996-1997 pp. (див. рисунок).

ериторія землекористув ння сільської р ди розмішен у меж х $л$ ндш фту сильно розчленов ної височини лісостепу з чорнозем ми типовими м логумусними $i$ чорнозем ми опідзоленими з фр гмент ми темно-сірих лісових грунтів, у минулому з гр бово-дубовими ліс ми $m$ різнотр вно-зл ковими степ ми, нині перев жсно розор ними. ілянк з йм є середню ч стину б сейну р. кв . рогр фічні умови території вирізняються глибоким вертик льним (50-60 м) і густим горизонт льним (1,00-1,25 км/км²) розчленув нням ярково-б лковою мережею. ередньозв жений пок зник крутості схилів л ндш фтних систем ст новить 4,4․ тупінь стійкості рельєфу земної поверхні ділянки щодо потенційної і ф ктичної вр зливості до процесів водної ерозії є сл бкостійким.

морфологічній структурі л ндш фту перев ж ють схилові л ндш фтні системи. окрем, л ндш фтні системи сл бковипуклих вододільних поверхонь п сом (0-1 $\left.{ }^{\circ}\right)$ 3 йм ють усього 5,6\% від 3 г льної площі землекористув ння сільської р ди; схилів крутістю $1-2^{\circ}-15,7 ; 2-3^{\circ}-16,8 ; 3-5^{\circ}-15,6 ; 5-7^{\circ}-22,8 ; 7-10^{\circ}-20,5 \%$. ндш фтні системи ерозійно небезпечних схилів крутістю пон д 2-3 3 йм ють 58,9 \% від з г льної площі дослідної ділянки. рім того, ктивному розвиткові ерозії грунтів у цьому регіоні зн чно сприяє дост тня кількість оп дів (540-580 мм/рік), висок інтенсивність злив (1,7-2,7 мм/хв), їхні великі добові м ксимуми (170-230 мм/добу) т зн чні з п си води в снігу (30-33 мм; ост нніми рок ми зн чно менше). структурі земельних угідь перев ж ють екологічно дест білізув льні угіддя - рілля т землі, виведені з сільсько- т лісогоспод рського виробництв (господ рські будівлі т помешк ння, дороги, к р'єри, землі стороннього користув ння). они з йм ють 89,7 \% (зокрем, рілля - 87,3\%) від їхньої з г льної площі. н вп ки, екологічно ст білізув льні угіддя (с ди, п совищ, сінож ті, ч г рники, лісосмуги, ліси, болот , води), 3 йм ють лише 8,96 \% від 3 г льної площі дослідної ділянки. н слідок цього грунти, охоплені ерозією, ст новлять 87,3 \% від їхньої 3 г льної площі. розія грунтів зумовил зниження їхньої родючості т зменшення врож йності сільськогоспод рських культур. ередньозв жені втр ти гумусу в грунт х орного горизонту (0-30 см) порівняно $з$ повнопрофільними ет лон ми- н лог ми (4,5\%) ст новлять 1,1 \%. 


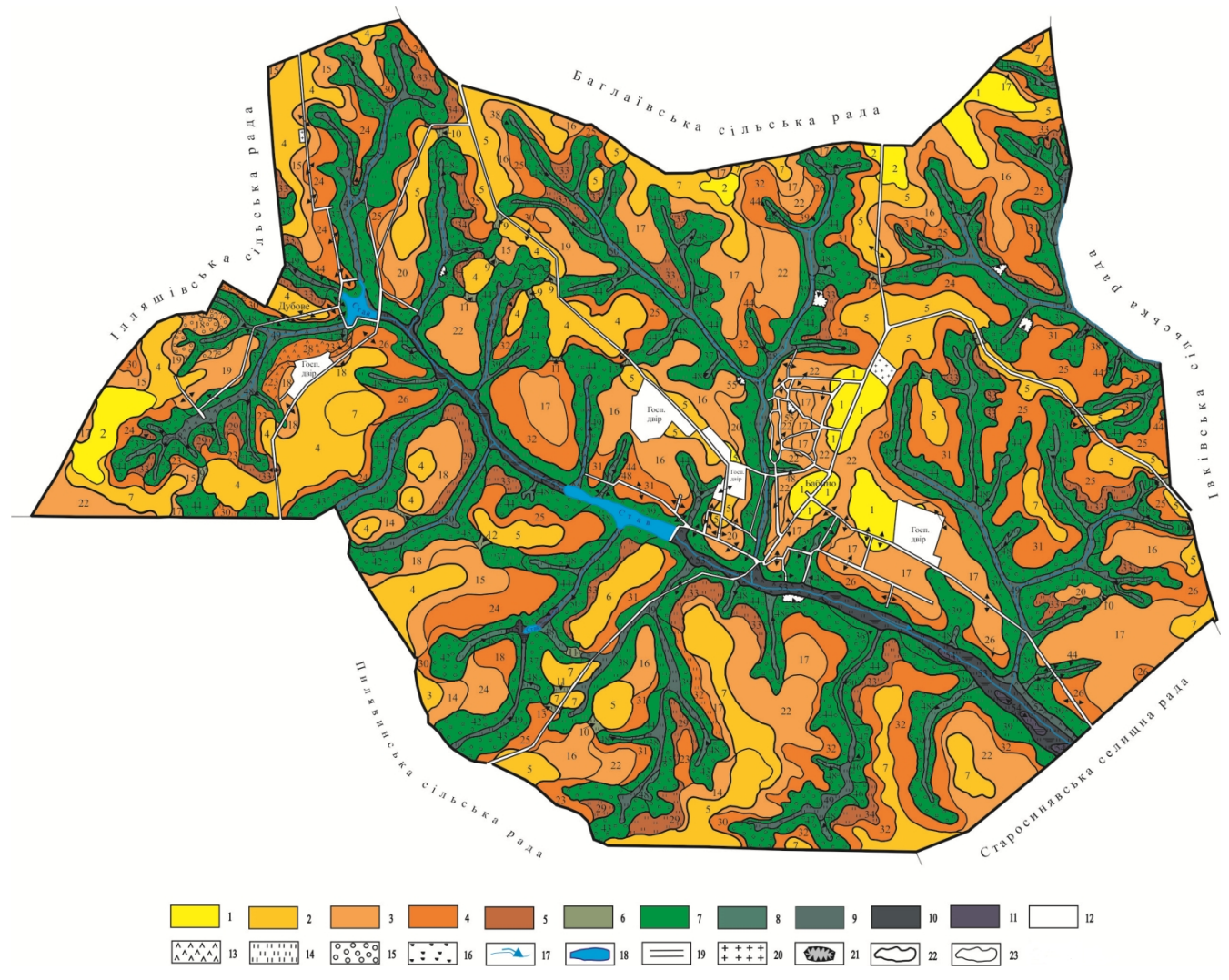

птимізов н структур земельних угідь бинської сільської р ди т росинявського р-ну мельницької обл.

Optimized land structure of Babyno community in Stara Syniava district in Khmelnytskyi region 1-11 - кольорові позн чення земельних угідь 3 скл дом т цільовим призн ченням у меж х л ндш фтних систем. емельні угіддя: 12 - рілля; 13 - п совищ ; 14 - сінож ті; 15 - ліси; 16 - болот . одні комплекси: 17 - допливи річок і струмки; 18 - ст ви. омунік ції: 19 - шосейні сф льтов ні т грунтові польові дороги. ісия похов нь: 20 - цвинт р. p'єрно-відв льні л ндш фтні системи: 21 - к р'єри видобутку піщ но-глинистих порід. ежі морфологічних одиниць: 22 - місцевостей; 23 - урочищ. ифр ми н к ртосхемі позн чено л ндш фтні системи - підурочищ т урочищ .

ндш фт сильно розчленов ної височини лісостепу з чорнозем ми типовими м логумусними т чорнозем ми опідзоленими з фр гмент ми сірих лісових грунтів, у минулому з гр боводубовими ліс ми і різнотр вно-зл ковими степ ми, нині перев жно розор ними.

ісцевість сл бковипуклих вододільних поверхонь п сом і привододільних схилів з чорнозем ми типовими м логумусними т чорнозем ми опідзоленими, розор ні. рочищ : 1 - сл бковипуклі вододільні поверхні п сом $\left(0-1^{\circ}\right)$ з покривом лесів і чорноземів неглибоких м логумусних вилугув них середньосуглинкових, під ріллю; 2 - сл бковипуклі вододільні поверхні п сом $\left(0-1^{\circ}\right)$ з покривом лесів і чорноземів глибоких м логумусних середньосуглинкових, під ріллю; 3 - привододільні сл бкопологі схили п сом крутістю 1-2 3 покривом лесів і чорноземів опідзолених сл бкозмитих середньосуглинкових, під ріллю; 4 - привододільні сл бкопологі схили п сом крутістю $1-2^{\circ}$ з покривом лесів і чорноземів неглибоких м логумусних 
вилугув них сл бкозмитих середньосуглинкових, під ріллю; 5 - привододільні сл бкопологі схили п сом крутістю 1-2 ${ }^{\circ}$ покривом лесів і чорноземів неглибоких м логумусних сл бкозмитих середньосуглинкових, під ріллю; 6 - привододільні сл бкопологі схили п сом крутістю 1-2 3 покривом лесів і чорноземів неглибоких м логумусних к рбон тних сл бкозмитих середньосуглинкових, під ріллю; 7 - привододільні сл бкопологі схили п сом крутістю 1-2 3 покривом лесів і чорноземів глибоких м логумусних сл бкозмитих середньосуглинкових, під ріллю; 8 - сідловини привододільних схилів п сом з покривом лесів і чорноземів опідзолених сл бкозмитих середньосуглинкових, під сінож ті з різнотр вно-зл ковою рослинністю; 9 - сідловини привододільних схилів п сом з покривом лесів і чорноземів неглибоких м логумусних вилугув них сл бкозмитих середньосуглинкових, під сінож ті 3 різнотр вно-зл ковою рослинністю; 10 - сідловини привододільних схилів п сом 3 покривом лесів і чорноземів неглибоких м логумусних сл бкозмитих середньосуглинкових, під сінож ті з різнотр внозл ковою рослинністю; 11 - сідловини привододільних схилів п сом з покривом лесів і чорноземів глибоких м логумусних сл бкозмитих середньосуглинкових, під сінож ті 3 різнотр вно-зл ковою рослинністю; 12 - сідловини привододільних схилів п сом 3 покривом лесів і чорноземів неглибоких м логумусних вилугув них середньозмитих середньосуглинкових, під сінож ті з різнотр вно-зл ковою рослинністю; 13 - сідловини привододільних схилів п сом 3 покривом лесів і чорноземів неглибоких м логумусних середньозмитих середньосуглинкових, під сінож ті з різнотр вно-зл ковою рослинністю.

ісцевість пологих і сп дистих схилів п сом. рочищ : 14 - сл бкопологі схили п сом крутістю 2-3 з покривом лесів і чорноземів опідзолених сл бкозмитих середньосуглинкових, під ріллю; 15 - сл бкопологі схили п сом крутістю 2-3 3 покривом лесів і чорноземів неглибоких м логумусних вилугув них сл бкозмитих середньосуглинкових, під ріллю; 16 - сл бкопологі схили п сом крутістю 2-3 3 покривом лесів і чорноземів неглибоких м логумусних сл бкозмитих середньосуглинкових, під ріллю; 17 - сл бкопологі схили п сом крутістю 2-3 3 покривом лесів і чорноземів глибоких м логумусних сл бкозмитих середньосуглинкових, під ріллю; 18 - пологі схили п сом крутістю 3-5³ покривом лесів і чорноземів опідзолених сл бкозмитих середньосуглинкових, під ріллю, т кож під з лишені н с дження гр боводубових лісів; 19 - пологі схили п сом крутістю 3-5 3 покривом лесів і чорноземів неглибоких м логумусних вилугув них сл бкозмитих середньосуглинкових, під ріллю; 20 - пологі схили п сом крутістю 3-5 3 покривом лесів і чорноземів неглибоких м логумусних сл бкозмитих середньосуглинкових, під ріллю; 21 - пологі схили п сом крутістю 3-5 3 покривом лесів і чорноземів глибоких м логумусних вилугув них сл бкозмитих середньосуглинкових, під ріллю; 22 - пологі схили п сом крутістю 3-5 3 покривом лесів і чорноземів глибоких м логумусних сл бкозмитих середньосуглинкових з плям ми середньозмитих 10-30, під ріллю; 23 - пологі схили п сом крутістю 3-5 3 покривом лесів і чорноземів опідзолених середньозмитих середньосуглинкових, під ріллю бо кормові угіддя (п совищ і сінож ті) з різнотр вно-зл ковою рослинністю; 24 - пологі схили п сом крутістю 3-5 3 покривом лесів і чорноземів неглибоких м логумусних вилугув них середньозмитих середньосуглинкових, під ріллю; 25 - пологі схили п сом крутістю 3-5 3 покривом лесів і чорноземів неглибоких м логумусних середньозмитих середньосуглинкових, під ріллю; 26 - пологі схили п сом крутістю 3-5 3 покривом лесів і чорноземів глибоких м логумусних середньозмитих середньосуглинкових, під ріллю; 27 - сл бкосп дисті схили п сом крутістю 5-7³ покривом лесів і чорноземів опідзолених сл бкозмитих середньосуглинкових, під гр бово-дубові ліси; 28 - сл бкосп дисті схили п сом крутістю 5-7³ покривом лесів, підстелених дочетвертинними глин ми 3 глибини 1,0-1,5 м, i темно-сірих опідзолених глеюв тих середньозмитих середньосуглинкових грунтів, під кормові угіддя з різнотр вно-зл ковою рослинністю (п совищ і сінож ті) бо з ліснення; 29 - сл бкосп дисті схили п сом крутістю 5-7 3 покривом лесів і чорноземів опідзолених сильнозмитих середньосуглинкових, під сінож ті з різнотр вно-зл ковою рослинністю; 30 - сл бкосп дисті схили п сом крутістю $5-7^{\circ}$ з покривом лесів і чорноземів неглибоких м логумусних вилугув них середньозмитих середньосуглинкових, під ріллю, т кож під з лишені н с дження гр бово-дубових лісів; 31 - сл бкосп дисті схили п сом крутістю 5-7³ покривом лесів і чорноземів неглибоких м ло- 
гумусних середньозмитих середньосуглинкових з плям ми сильнозмитих 10-30, під ріллю; 32 - сл бкосп дисті схили п сом крутістю 5-7 3 покривом лесів і чорноземів глибоких м логумусних середньозмитих середньосуглинкових з плям ми сильнозмитих 10-30, під ріллю; 33 - сл бкосп дисті схили п сом крутістю 5-7 3 покривом лесів і чорноземів типових м логумусних сильнозмитих середньосуглинкових, під сінож ті з різнотр вно-зл ковою рослинністю; 34 - сл бкосп дисті схили п сом крутістю 5-7 3 покривом лесів, підстелених дочетвертинними глин ми з глибини 0,5 1,0 м, і чорноземів моч ристих сильнозмитих середньосуглинкових, під сінож ті з різнотр вно-зл ковою рослинністю.

ісцевість ярково-б лкової мережі. рочищ : 35 - сл бкопологі схили б лок крутістю $2-3^{\circ} 3$ покривом лесів і чорноземів глибоких м логумусних сл бкозмитих середньосуглинкових, під сінож ті з різнотр вно-зл ковою рослинністю; 36 - пологі схили 6 лок крутістю $3-5^{\circ} 3$ покривом лесів і чорноземів глибоких м логумусних сл бкозмитих середньосуглинкових, під сінож ті 3 різнотр вно-зл ковою рослинністю; 37 - сл бкосп дисті схили б лок крутістю 5-7 3 покривом лесів і чорноземів неглибоких м логумусних вилугув них середньозмитих середньосуглинкових, під кормові угіддя з різнотр вно-зл ковою рослинністю (сінож ті, п совищ ) бо з ліснення; 38 - сл бкосп дисті схили б лок крутістю 5-7³ покривом лесів і чорноземів неглибоких м логумусних середньозмитих середньосуглинкових з плям ми сильнозмитих 10-30, під кормові угіддя 3 різнотр вно-зл ковою рослинністю (сінож ті, П совищ ) бо з ліснення; 39 - сл бкосп дисті схили б лок крутістю 5-7 3 покривом лесів і чорноземів глибоких м логумусних середньозмитих середньосуглинкових з плям ми сильнозмитих 10-30, під кормові угіддя з різнотр вно-зл ковою рослинністю (сінож ті, п совищ ) бо з ліснення; 40 - сл бкосп дисті схили 6 лок крутістю 7-10³ покривом лесів і темно-сірих опідзолених середньозмитих середньосуглинкових грунтів з плям ми розмитих 10-30, під гр бово-дубові ліси; 41 - сл бкосп дисті схили 6 лок крутістю 7-10 3 покривом лесів, підстелених дочетвертинними глин ми 3 глибини 1,0-1,5 м, і темно-сірих опідзолених глеюв тих сильнозмитих середньосуглинкових грунтів, під гр бово-дубові ліси бо кормові угіддя з різнотр вно-зл ковою рослинністю (п совищ і сінож ті); 42 - сл бкосп дисті схили б лок крутістю 7-10 3 покривом лесів і чорноземів опідзолених сл бкозмитих середньосуглинкових з плям ми розмитих 10-30, під гр бово-дубові ліси; 43 - сл бкосп дисті схили б лок крутістю 7-10 3 покривом лесів і чорноземів опідзолених сильнозмитих середньосуглинкових, під гр бово-дубові ліси; 44 - сл бкосп дисті схили $\left(7-10^{\circ}\right)$ л лок 3 покривом лесів і чорноземів типових м логумусних сильнозмитих середньосуглинкових, під гр бово-дубові ліси; 45 - сл бкосп дисті схили б лок крутістю 7-10 3 покривом лесів, підстелених дочетвертинними глин ми з глибини 1,0-1,5 м, i чорноземів опідзолених глеюв тих сильнозмитих середньосуглинкових, під гр бово-дубові ліси; 46 - сл бкосп дисті схили б лок крутістю 7-10 $з$ покривом лесів, підстелених дочетвертинними глин ми з глибини 1,0-1,5 м, і чорноземів моч ристих середньозмитих середньосуглинкових, під гр бово-дубові ліси; 47 - сл бкосп дисті схили б лок крутістю 7-10 $з$ покривом лесів, підстелених дочетвертинними глин ми з глибини 0,5-1,0 м, і чорноземів моч ристих сильнозмитих середньосуглинкових, під гр бово-дубові ліси; 48 - днищ верхів'їв б лок з покривом суч сних делюві льних відкл дів і лучно-чорноземних н митих середньосуглинкових грунтів, під кормові угіддя (сінож ті, п совищ ) з різнотр вно-зл ковою рослинністю бо з ліснення (гр бово-дубові ліси); 49 - днищ б лок з покривом суч сних люві льно-делюві льних відкл дів і лучних н митих середньосуглинкових грунтів, під кормові угіддя (сінож ті, п совищ ) з різнотр внозл ковою рослинністю; 50 - днищ б лок з покривом суч сних люві льно-делюві льних відкл дів і лучно-болотних середньосуглинкових грунтів, під сінож ті з осоково-різнотр вною рослинністю; 51 - днищ 6 лок 3 покривом суч сних люві льно-делюві льних відкл дів і мулув то-болотних грунтів, під болото з очеретяно-осоковою рослинністю.

ісцевість допливів р. кв . рочищ : 52-3 пл в середнього рівня з покривом люві льноделюві льних відкл дів і лучних середньосуглинкових грунтів, під кормові угіддя з різнотр внозл ковою рослинністю (сінож ті, п совищ ); 53 - з пл в низького рівня 3 покривом люві льноделюві льних відкл дів і лучно-болотних середньосуглинкових грунтів, під сінож ті з осоково- 
різнотр вною рослинністю; 54 - 3 пл в низького рівня з покривом люві льно-делюві льних відкл дів і мулув то-болотних грунтів, під болото з очеретяно-осоковою рослинністю.

р'єрно-відв льні л ндш фтні системи: 55 - к р'єри видобутку піщ но-глинистих порід. ісля рекультив ції-штучне з ліснення бо з луження.

омунік ції - шосейні сф льтов ні т грунтові польові дороги. бов'язкові придорожні стрічкові лісові бо ч г рникові н с дження.

озміщення земельних угідь 3 скл дом т цільовим призн ченням, т кож гросівозміни в їхніх меж х виокремлено кольор ми:

- 1 - польові зерно-п ропрос пні сівозміни і вирощув ння всіх сільськогоспод рських культур цієї зони з використ нням інтенсивних систем землеробств т широким впров дженням їхніх екологічних л нок;

- 2-3 - польові зерно-п ропрос пні сівозміни і вирощув ння всіх сільськогоспод рських культур цієї зони з використ нням екологічних систем землеробств 3 умови оброблення грунту, сівби т догляду з посів ми у н прямі горизонт лей. бов'язкові придорожні водоохоронні т грунтоз хисні стрічкові лісові й ч г рникові н с дження. потреби кормові угіддя - П совищ і сінож ті;

- 4 - польові зерно-тр в’яні бо тр в’яно-зернові грунтоз хисні сівозміни з повним вилученням прос пних культур. бов'язкові придорожні водоохоронні т грунтоз хисні стрічкові лісові н с дження;

- 5, 6 - штучне бо природне з луження. поч тку сінокісне призн чення, в м йбутньому, через п’ять-сім років, - п совищне. потреби з ліснення;

- 7, 8-м лоприд тні для кормових угідь схили і днищ верхів’їв б лок призн чені під з ліснення. потреби штучне бо природне з луження. поч тку сінокісне призн чення, в м Йбутньому, через сім-десять років, - п совищне. бов'язкові прирічкові стрічкові лісові бо ч г рникові н с дження;

- 9, 10 - природне з луження - кормові угіддя (сінож ті, п совищ );

- 11 - болот .

ісля вироблення к р’єрів обов’язкове штучне з ліснення бо з луження, н вколо доріг - придорожні стрічкові лісові бо ч г рникові н с дження.

птиміз ція структури земельних угідь з ур хув нням скл дної л ндш фтної будови дослідної ділянки з свідчує, що в меж х л ндш фту сильнорозчленов ної височини лісостепу з чорнозем ми типовими м логумусними і чорнозем ми опідзоленими 3 фр гмент ми темно-сірих лісових грунтів орні землі повинні з йм ти не більше $45,4 \%$ (1 503,1 г ) від з г льної площі території сільської р ди. окрем : 2,6 \% (87,5 г ) рекомендов но використовув ти під польові зерно-п ропрос пні сівозміни і вирощув ння всіх сільськогоспод рських культур цієї зони з з стосув нням інтенсивних систем землеробств т широким впров дженням їхніх екологічних л нок; 27,8 \% (918,3 г ) - під польові зерно-п ропрос пні сівозміни і вирощув ння всіх сільськогоспод рських культур цієї зони з використ нням екологічних систем землеробств 3 умови оброблення грунту, сівби т догляду з посів ми у н прямі горизонт лей; 15,0 \% (497,3 г ) - під польові зерно-тр в’яні бо тр в'яно-зернові грунтоз хисні сівозміни 3 повним вилученням прос пних культур. е менше 51,2 \% (1 700 г ) від з г льної площі дослідної ділянки повинні з йм ти б г торічні н с дження (с ди) (1,6 \% (52,8 г )), п совищ $(0,9(28,4))$, сінож ті $(20,9(695,1))$, лісосмуги $(0,05(1,6))$, ліси $(27,1(897,6))$, болот $(0,21(5,9))$, води $(0,54 \%(18,6$ г $))$. ешту $3,4 \%(107,2$ г ) з йм ють господ рсь- 
кі будівлі т помешк ння $(1,2 \%(38,0$ г )), дороги $(1,1(36,9))$, порушені землі (к р'єри) $(0,2(6,1))$ і землі стороннього користув ння $(0,9 \%(26,2$ г $)$.

трим ні результ ти д ли змогу обгрунтув ти норми сприятливого співвідношення земельних угідь для території землекористув ння бинської сільської р ди, їхній н ліз свідчить, що для сильнорозчленов них височин лісостепу ст білізув льні угіддя м ють 3 йм ти не менше 50-55\%. н вп ки, дест білізув льні - не більше 50-45\% (зокрем , рілля - 40-45\%). кі дослідження є першим кроком до створення ст лих л ндш фтно-екологічних систем 3 принципом відновлення земельних ресурсів i посилення процесів їхньої стійкості т с морегулюв ння 3 вдяки розширенню площі екологічно ст білізув льних земельних угідь м лопродуктивних земель.

м йбутньому з держ вного бюджету необхідно виділяти кошти суб'єкт м пр в вл сності н землю для переобстеження грунтів 3 використ нням нових технологій і технічного з безпечення. підст ві отрим них результ тів потрібно оптимізув ти структуру земельних угідь з ур хув нням л ндш фтної будови території землекористув нь. е з безпечить повноту інформ ції для укл д ння держ вного земельного (грунтового, л ндш фтного) к д стру і проведення соці льно-економічної т економічної оцінок земель.

1. inm ч ., укурудз . етриз ція екологічного ст ну земельних ресурсів лісостепових л ндш фтів : моногр фія. ьвів : ид вничий центр імені в н p HK , 2002. $119 \mathrm{c}$.

2. inm ч . емлі кр їни: к тегорії, пр во вл сності, ст н використ ння, охорон : н вч. посібник. ьвів : ид вничий центр імені в н р нк, 2010. 240 с.

3. inm 4 . ідновлюв льне природокористув ння // існик ьвів. ун-ту. ер. геогр. 2015. ип. 49. . 111-120. DOI: http://dx.doi.org/10.30970/vgg.2015.49.8611

\section{REFERENCES}

1. Kiptach, F., \& Kukurudza, S. (2002). Metrication of the ecological state of land resources of forest-steppe landscapes. Lviv: Publishing center of Ivan Franko National University of Lviv, 119 p. (in Ukrainian).

2. Kiptach, F. (2010). Lands of Ukraine: categories, rights, using, protection. Lviv: Publishing center of Ivan Franko National University of Lviv, 240 p. (in Ukrainian).

3. Kiptach, F. (2015). Renewable using of natural resources. Visnyk of the Lviv University. Series Geography, 49, 111-120. DOI: http://dx.doi.org/10.30970/vgg.2015.49.8611 (in Ukrainian). 


\title{
OPTIMIZATION OF THE LAND USE WITH CONSIDERING OF THE LANDSCAPE STRUCTURE OF THE TERRITORY ON THE TEST SITES
}

\section{Fedir Kiptach}

\author{
Ivan Franko National University of Lviv, \\ P. Doroshenko St., 41, UA - 79007 Lviv, Ukraine, \\ e-mail:kfgeoresurs@ukr.net
}

The large-scale landscape maps necessity in developing projects and proposals for agriculture, forestry land-use and erosion protection were justified. Natural conditions of land-use in Babyno community in Stara Syniava district in Khmelnytskyi region were described and analyses of the land structure were made. Accordingly, the land structure is characterised by ecologically destabilising lands, including arable lands, lands that were withdrawn from agriculture production and forestry (outbuildings, houses, roads, quarries, exterior use lands) are prevailing. They are covered $89.7 \%$ (in particular, arable lands $-87.3 \%$ ) of total community lands. And, vice versa, ecologically stabilising lands (gardens, pastures, grasslands, shrubs, forest belts, forests, swamps, water covered lands) are covered a small percentage -8.96 of the total research area. Therefore, soil erosion is covered $87.3 \%$ of the total area - a significant percentage. Soil erosion caused decreasing of soil fertility and yields of agriculture. The average weighted losses of humus in the arable horizon of soils $(0-30 \mathrm{~cm})$ compared with full-profile standard analogues are $1.1 \%$. The first step of developing sustainable ecological landscape systems was justified by using a principle of land resource restoration and strengthening of their self-regulation through increasing the area of ecologically stabilised lands by low productivity lands and by their location with taking into consideration a complex morphological structure of landscape systems. Landscape systems of research area were classified by genesis and type of their economic use. Arable lands should cover no more than $45.4 \%$ of the total community area. In particular, $2.6 \%$ is recommended to use for field grain-steam tilled crop rotations and cultivating all agriculture crops of this zone by using intensive agriculture systems and the widespread introduction of their ecological links; $27.8 \%$ is recommended to use for field grain-steam tilled crop rotations and cultivating all agriculture crops of this zone by using ecological systems of agriculture provided soil cultivation, sowing and caring for crops according to the elevation line directions. $15.0 \%$ - for field grain-grass or grass-grain soil protected crop rotations with the total exclusion of row crops. $51.2 \%$ of total community land area should be covered by perennial plants $(1.6 \%)$, grasslands $(0.9 \%)$, shrubs and forest belts $(0.05 \%)$, forests $(27.1 \%)$, swamps $(0.21 \%)$, lands covered by water $(0.54 \%)$. Other $3.4 \%$ are covered by outbuildings and houses $(1.2 \%)$, roads $(1.1 \%)$, open-casts $(0.2 \%)$ and exterior use lands $(0.9 \%)$. The results of research helped to justify the rules of the rational use of land area in Babyno community and its analysis suggests that land area of the heavily dissected hills of the foreststeppe stabilising land should occupy at least 50-55\%. Conversely, destabilising - no more than 50-45\% (particularly arable land $-40-45 \%$ ).

Key words: optimization of the land use, soil erosion, lands, landscape systems. 